\title{
Change in Kinetic parameters of commercial yeast in the presence of copper fungicides
}

\author{
Angelo Gava, Evandro Ficagna, Simone B. Rossato, Bruno Cisilotto, Shana P.S. Miotto, and Henrique T. Gabbi \\ Instituto Federal de Educação, Ciência e Tecnologia do Rio Grande do Sul, Campus Bento Gonçalves, Brasil
}

\begin{abstract}
The Serra Gaucha has a high rainfall occurrence during the ripening and harvest. It results in higher use of fungicides, being the copper-based ones, the most commonly used. High levels of this metal can cause stress to the yeast, thus, influencing on the fermentation kinetics. The aim of this study was to evaluate the fermentative behavior of oenological yeast in the presence of copper content in the must. The experiment used the following fungicides: Copper Sulfate, Copper Oxychloride and Copper Hydroxide. Samples were inoculated with S. cerevisiae, S. cerevisiae var. bayanus and Torulaspora delbrueckii and the fermentation was plotted for carbon dioxide production by time. The fermentative kinetics were assessed by the following kinetic parameters: the lag phase time, maximum rate of $\mathrm{CO} 2$ production and maximum production of $\mathrm{CO} 2$. The study showed that $T$. delbrueckii had higher sensitivity to copper regarding the lag phase. Copper oxychloride promoted greater latency period in yeast $T$. delbrueckii and $S$. cerevisiae. All copper fungicides decreased maximum rate of fermentation, and T. delbrueckii was the most affected. The maximum $\mathrm{CO} 2$ production during the fermentations significantly differed only in the presence of copper sulphate.
\end{abstract}

\section{Introduction}

The Hill Top Northeast Sierra (Sierra Gaucha) is the main wine-growing region of Rio Grande do Sul State and Brazil. This region, although considered climatically viable for the processing of grapes [1], has high rainfall occurrence during the ripening and harvest periods. The viability of the grape cultivation in this region requires preventive and frequent application of chemicals for the control of fungal diseases on the aerial part of the plant. Spraying fungicides and the use of resistant cultivars are some of the methods usually recommended for the management of some fungal diseases such as downy mildew [2]. The control method most frequently adopted by manufacturers is spraying contact and systemic fungicides [3], which require multiple applications during the growth and production cycle of the vine [4]. Moreover, in order to avoid damage caused by the rain, the harvest is, many times, anticipated and the fruit does not get to the ideal commercial ripening. The applications are even more frequent for Vitis vinifera grapes because those varieties are more susceptible to diseases and they are the most valued grapes in the market [5].

Since the late seventeenth century, copper has been used to fight fungal diseases of the vines, and its use was intensified at the end of the nineteenth century [6]. Since then, grape growers have continuously and repeatedly applied it to the vines in the form of spray. Coppermetal-containing substances are highly efficient against pathogens that can attack vines, mainly against downy mildew, commonly found in the Serra Gaucha region, powdery mildew and other varieties of pests and pathogens [7-9].
Copper $(\mathrm{Cu})$ is an essential micronutrient for plants, animals and humans as a constituent of numerous enzymes and as a catalyst for redox reactions in various metabolic pathways [10]. However, its optimal concentration range is very narrow, and when higher than it, the metal can be inhibitory. For yeast cells, especially Saccharomyces cerevisiae, different levels of this metal in adverse conditions can cause stress. Therefore, it can influence cell growth and fermentative kinetics. The stress may compromise the plasma membrane and stop cell growth and reproduction, resulting in cell death [11]. Thus, there may be changes in the duration of the lag phase, the maximum rate of fermentation and complete degradation of sugars.

Studies show that the yeast has certain absorption capacity of heavy metals, especially yeast of the species Saccharomyces cerevisiae, which have significant results in the absorption of heavy ions. Different yeast species have different absorption rates of the $\mathrm{Cu}^{+2}$ metal and consequently different resistance to it [12-15].

The residual concentration in musts resulted from fruit, or use of fungal treatments, is related to copper rate applied throughout growing season, the quantity of the applications, and the amount of rainfall between application and harvest [16]. The current legislation in South Africa considers in the legal parameters any concentration up to $20 \mathrm{mg} \mathrm{L}^{-1} \mathrm{Cu}^{2+}$ in the grape berries [17]. According to [18] metal concentrations found in wine are around 6 to 19 times lower than doses observed in the fruit itself, so it can be assumed that much waste is disposed over the winemaking process. According to [19], $\mathrm{Cu}$ concentrations can reach up to $3 \mathrm{mg} \mathrm{L}^{-1}$ in the must. However, the value found from this metal may 
be much higher, reaching values up to $15 \mathrm{mg} \mathrm{L}^{-1}$ and $26 \mathrm{mg} \mathrm{L}^{-1}$ [20-22] observed the presence of metal in musts of Concord and Isabel varieties, finding maximum values of 9.28 and $12.89 \mathrm{mg} \mathrm{L}^{-1}$, respectively. [23] analyzed musts from eight different vineyards of Cabernet Franc in Serra Gaucha and found an average of $5.4 \mathrm{mg} \mathrm{L}^{-1}$, and a range of 2.3 to $13.4 \mathrm{mg} \mathrm{L}^{-1}$ of $\mathrm{Cu}^{2+}$, which was related to the amount and time of the application.

Thus, this study aimed to assess the sensitivity of different oenological commercial yeast Saccharomyces and non-Saccharomyces copper content present in wine.

\section{Materials and methods}

\subsection{Must}

It was used 6L of must, homogenized with $20 \%$ of fermentable sugars at $\mathrm{pH} 3.15$. The juice was obtained from grapes of Isabel and Bordô varieties (hybrids and Vitis labrusca). They were harvested from the IFRS experimental station - Campus Bento Gonçalves, and the plants had known and controlled phytosanitary treatments during the growing season. The juice was obtained from the processes of destemming, crushing, pasteurization $\left(85^{\circ} \mathrm{C} / 2 \mathrm{~min}\right.$ ), enzyme addition (commercial pectinase $20 \mathrm{mg} \mathrm{L}^{-1}$, two hours at about $45^{\circ} \mathrm{C}$ ), filtration, pasteurization $\left(85^{\circ} \mathrm{C} / 1 \mathrm{~min}\right)$ and packaging in glass containers. We chose to use these varieties to be widely disseminated and adapted to the climate and soil of the Serra Gaucha, representing a significant portion of the grapes processed in the region [24]. Moreover, they are hardy varieties whose needs of phytosanitary treatments are smaller than the varieties Vitis vinifera [25], reducing risks of interference must in the experiment.

\subsection{Microorganisms}

The samples were inoculated with three different commercial yeast: Saccharomyces cerevisiae var. cerevisiae (Zymaflore X5, Laffort, France), Saccharomyces cerevisiae var. bayanus (La Claire SP 665/P, PerdominiIOC, Italy), e Torulaspora delbrueckii (Zymaflore Alpha, Laffort, France). The yeast was acclimatized and hydrated with distilled water at $35^{\circ} \mathrm{C}$ for 15 minutes, except Torulaspora $d .30^{\circ} \mathrm{C}$, as recommended by the suppliers. After acclimation, the yeast was inoculated to the juice using the same dose for all the different yeasts $\left(30 \mathrm{~g} \mathrm{hL}^{-1}\right)$.

\subsection{Cupric fungicides}

The added copper levels were established based on a previous biography, so the experiment aimed concentrations of 6 and $12 \mathrm{mg} \mathrm{L}^{-1}$ of the metal. The following were used fungicides: Copper Sulfate Pentahydrate [Molecular Formula: $\mathrm{CuSO}_{4} .5 \mathrm{H}_{2} \mathrm{O}$ ] (Commercial name: Microsal); Copper Oxychloride [Molecular Formula: $\mathrm{Cu}_{2} \mathrm{Cl}(\mathrm{OH})_{3}$ ] (Commercial name: Recop) and Copper hydroxide [Molecular Formula: $\mathrm{Cu}(\mathrm{OH})_{2}$ ] (Commercial name: Ellect).

\subsection{Fermentation}

The fermentations were conducted in quadruplicate in containers of $45 \mathrm{~mL}$ at $25^{\circ} \mathrm{C}$, and they were plotted by the production of carbon dioxide $\left(\mathrm{CO}_{2}\right)$ as a function of time,
Table 1. - Interference from copper fungicides on the lag phase (hours) of yeast.

\begin{tabular}{|l|l|l|l|}
\hline & $\begin{array}{l}\text { Copper } \\
\text { hydroxide }\end{array}$ & $\begin{array}{l}\text { Copper } \\
\text { Sulfate }\end{array}$ & $\begin{array}{l}\text { Copper } \\
\text { oxychloride }\end{array}$ \\
\hline S. cerevisiae & $22.44 \mathrm{cB}$ & $23.03 \mathrm{cAB}$ & $23.40 \mathrm{cA}$ \\
\hline T. delbrueckii & $54.74 \mathrm{aB}$ & $54.27 \mathrm{aB}$ & $58.87 \mathrm{aA}$ \\
\hline $\begin{array}{l}\text { S. cerevisiae } \\
\text { var. bayanus }\end{array}$ & $27.32 \mathrm{bA}$ & $27.21 \mathrm{bA}$ & $27.39 \mathrm{bA}$ \\
\hline
\end{tabular}

Values with different capital letters in the single columns (fungicides) and different small letters in the single rows (yeast) are statistically different. Tukey's test $(\mathrm{p}<0.05)$.

due to loss of mass daily. The fermentation was monitored by measuring the mass balancing static on containers every 12 hours, over approximately 6 days. The fermentation was considered complete when evolution of $\mathrm{CO}_{2}$ (mass loss) stopped.

\subsection{Kinetic parameters}

The fermentative kinetics were assessed by the following kinetic parameters according to [26]: Time of lag phase (hours) by production of $\mathrm{CO}_{2}$, the maximum rate of $\mathrm{CO}_{2}$ production $\left(\mathrm{g} \mathrm{L}^{-1} \mathrm{~h}^{-1}\right)$ and maximum $\mathrm{CO}_{2}$ production $\left(\mathrm{g} \mathrm{L}^{-1}\right)$. Those parameters were obtained through the nonlinear sigmoidal fit of the modified Gompertz equation (equation 1) according [27], which importance for the activity in oenological research has been reported by $[28,29]$.

$$
y=A \exp \left\{-\exp \left[\frac{\mu_{m} \cdot \epsilon}{A}(\lambda-t)+1\right]\right\} .
$$

It was used Software "Predictive Modelling Program Integrated Tools" USDA [30] for evaluation of the model and obtaining parameters.

\subsection{Experimental design and statistical analysis}

The experiment was designed in a full factorial arrangement $(3 \times 3 \times 3)$ with three factors: 3 pesticides, 3 contents copper present in the must $\left(0,6\right.$ and $\left.12 \mathrm{mg} \mathrm{L}^{-1}\right)$ and 3 commercial yeast. The results were evaluated by analysis of variance (ANOVA) at $1 \%$ probability followed by Tukey test $(\mathrm{p}<0.05)$ through software Assistant [31].

\section{Results and discussion}

The study showed effect of different cupric products on the duration the lag phase, and T. delbrueckii presented the greatest sensitivity. There was also differentiation between products. Copper oxychloride promoted longer lag phase in $T$. delbrueckii and Saccharomyces cerevisiae, but it did not affect $S$. bayanus (Table 1). For all yeasts there was no significant difference between the control and the dose of $12 \mathrm{mg} . \mathrm{L}^{-1} \mathrm{Cu}$ present in the must. [32] stated that there was no inhibition for activity at a dose of $16 \mathrm{mg} \mathrm{L}^{-1}$ copper in the first 100 hours of fermentation.

All copper fungicides caused decrease on the values of maximum rate of fermentation for all species. T. delbrueckii was the most affected species by the presence of the products. [33] stated that musts containing $20 \mathrm{mg} \mathrm{L} \mathrm{L}^{-1}$ added copper reduced their fermentative activity drastically. There were significant differences in 
Table 2. Interference of cupric fungicides on Fermentation Maximum Rate $\left(\mathrm{g} \mathrm{L}^{-1} \mathrm{~h}^{-1}\right)$ of the yeasts.

\begin{tabular}{|l|l|l|l|}
\hline & $\begin{array}{l}\text { Copper } \\
\text { hydroxide }\end{array}$ & $\begin{array}{l}\text { Copper } \\
\text { Sulfate }\end{array}$ & $\begin{array}{l}\text { Copper } \\
\text { oxychloride }\end{array}$ \\
\hline S. cerevisiae & $2,01 \mathrm{bA}$ & $2,00 \mathrm{bA}$ & $2,00 \mathrm{bA}$ \\
\hline T. delbrueckii & $1,91 \mathrm{bA}$ & $1,47 \mathrm{cB}$ & $1,33 \mathrm{cC}$ \\
\hline $\begin{array}{l}\text { S. cerevisiae } \\
\text { var. bayanus }\end{array}$ & $2,27 \mathrm{aA}$ & $2,18 \mathrm{aA}$ & $2,20 \mathrm{aA}$ \\
\hline
\end{tabular}

Values with different capital letters in the single columns (fungicides) and different small letters in the single rows (yeast) are statistically different. Tukey's test $(\mathrm{p}<0.05)$.

Table 3. Effects of fungicides and their doses applied on the maximum rate of fermentation.

\begin{tabular}{|l|l|l|l|}
\hline & $\mathbf{0 ~} \mathbf{m g ~ L}^{-\mathbf{1}}$ & $\mathbf{6} \mathbf{~ m g ~ \mathbf { L } ^ { - 1 }}$ & $\mathbf{1 2} \mathbf{~ m g ~ L}^{-\mathbf{1}}$ \\
\hline Copper hydroxide & $2,19 \mathrm{aA}$ & $2,08 \mathrm{aA}$ & $1,92 \mathrm{aB}$ \\
\hline Copper Sulfate & $2,18 \mathrm{aA}$ & $1,87 \mathrm{bB}$ & $1,59 \mathrm{bC}$ \\
\hline Copper oxychloride & $2,16 \mathrm{aA}$ & $1,83 \mathrm{bB}$ & $1,51 \mathrm{bC}$ \\
\hline
\end{tabular}

Values with different capital letters in the single columns (concentration) and different small letters in the single rows (fungicides) are statistically different.

Tukey's test $(\mathrm{p}<0.05)$.

Table 4. Interference of Fungicides cupric dose on the studied kinetic parameters.

\begin{tabular}{|l|l|c|c|}
\hline & $\mathbf{L a g} \mathbf{( h )}$ & $\mu_{\max }\left(\mathbf{g ~ L}^{-1} \mathbf{h}^{-1}\right)$ & $\mathbf{C O}_{2 \operatorname{Max}}\left(\mathbf{g ~ L}^{-1}\right)$ \\
\hline $0 m g L^{-1}$ & $32,4 \mathrm{~b}$ & $2,19 \mathrm{a}$ & $99,98 \mathrm{a}$ \\
\hline $6 m g L^{-1}$ & $36,96 \mathrm{a}$ & $1,93 \mathrm{~b}$ & $99,5 \mathrm{a}$ \\
\hline $12 m g L^{-1}$ & $36,72 \mathrm{a}$ & $1,67 \mathrm{c}$ & $96 \mathrm{~b}$ \\
\hline
\end{tabular}

Values with different letters in the single columns are statistically different. Tukey's test $(\mathrm{p}<0.05)$.

sensitivity to cupric products in the following decreasing order: copper oxychloride > Copper sulfate > copper hydroxide (Table 2).

Among the products, the oxychloride and sulfate copper showed a higher effect on fermentation than copper hydroxide. The hydroxide had effect only at a dose of $12 \mathrm{mg} \mathrm{L}^{-1}$, while the other products showed effects also at the dose of $6 \mathrm{mg} \mathrm{L}^{-1}$ (Table 3) on all the yeasts except for $S$. cerevisiae.

It was observed that the dose of $12 \mathrm{mg} \mathrm{L}^{-1}$ of copper caused interference at the maximum carbon dioxide production $\left(\mathrm{CO}_{2} \mathrm{Max}\right)$ compared to control (Table 4). [34] found similar results in their work. The fermentation rate $(\mu \max )$ was decreased whenever the dose of $12 \mathrm{mg} \mathrm{L}^{-1}$ was used in comparative to the dose $6 \mathrm{mg} \mathrm{L}^{-1}$.

The maximum $\mathrm{CO}_{2}$ production during the fermentations significantly differed only in the presence of copper sulphate to $T$. delbrueckii (Table 5). Whereas treatment with other products in different concentrations did not differ from the control treatment. [35] reported a decrease of approximately $80 \%$ of $\mathrm{CO}_{2}$ production in the first 10 days when using copper sulphate at a dose of $32 \mathrm{ppm}$ of copper.

\section{Conclusions}

The effect of copper on yeasts is dependent on the fungicide that gives rise to the metal in the must. Different yeasts behave differently in the presence of copper in the must, and the yeast $T$. delbrueckii demonstrated greater sensitivity to copper compared the yeast Saccharomyces.
Table 5. Interference of cupric fungicides for producing carbon dioxide Maximum $\left(\mathrm{g} \mathrm{L}^{-1}\right)$.

\begin{tabular}{|l|l|l|l|}
\hline & $\begin{array}{l}\text { Copper } \\
\text { hydroxide }\end{array}$ & $\begin{array}{l}\text { Copper } \\
\text { Sulfate }\end{array}$ & $\begin{array}{l}\text { Copper } \\
\text { oxychloride }\end{array}$ \\
\hline S. cerevisiae & $101,17 \mathrm{aA}$ & $100,54 \mathrm{aA}$ & $100,66 \mathrm{aA}$ \\
\hline T. delbrueckii & $99,28 \mathrm{aA}$ & $91,88 \mathrm{bB}$ & $96,18 \mathrm{bA}$ \\
\hline $\begin{array}{l}\text { S. cerevisiae var. } \\
\text { bayanus }\end{array}$ & $99,16 \mathrm{aA}$ & $99,90 \mathrm{aA}$ & $98,54 \mathrm{abA}$ \\
\hline
\end{tabular}

Values with different capital letters in the single columns (fungicides) and different small letters in the single rows (yeast) are statistically different. Tukey's test $(\mathrm{p}<0.05)$.

\section{References}

[1] Westphalen, S. L., and J. R. T. Maluf. Caracterização das áreas bioclimáticas para o cultivo de Vitis vinifera L.: regiões da Serra do Nordeste e Planalto do Estado do Rio Grande do Sul. Embrapa Comunicação para Transferência de Tecnologia/Bento Gonçalves (2000)

[2] Amorim, L., et al. "Doenças da videira (Vitis spp.)." Kimati, H.; Amorim, L.; Rezende, JAM; Bergamin Filho, A, 639-651 (2005)

[3] Sônego, O. R., L. da R. Garrido, and A. Grigoletti Júnior. Principais doenças fúngicas da videira no Sul do Brasil. Vol. 38. Embrapa Uva e Vinho (2005)

[4] Madden, L. V., et al. "Evaluation of a disease warning system for downy mildew of grapes." Plant Disease. 84.5, 549-554 (2000)

[5] Chadha, K. L., and S. D. Shikhamany. The grape: improvement, production and post-harvest management. Malhotra Publishing House (1999)

[6] Komárek, Michael, et al. "Contamination of vineyard soils with fungicides: a review of environmental and toxicological aspects." Environment international 36.1, 138-151 (2010)

[7] Boubals, D. "Copper in the control of grapes in France.” Vignevini, 28.5, 45-47 (2001)

[8] Ferreira, J. C., Strecht, A., Ribeiro, J. R., Soeiro, A., \& Cotrim, G. Manual de Agricultura Biologica. Lisboa: Agrobio (1998)

[9] Morando, A., Morando, P., Bevione, D., \& Lembo, S. Vite e rame: l'impiego del rame fra pregi e difetti; Il controllo della peronospora in vigneto con rameici a dosaggi ridotti. Vignevini, 24(7-8), 53-57 (1997)

[10] Devez A, Gomez E, Gilbin R, Elbaz-Poulichet F, Persin F, Andrieux P, et al. Assessment of copper bioavailability and toxicity in vineyard runoff waters by DPASV and algal bioassay. Sci Total Environ: 348, 82-92 (2005)

[11] Brandolini, V., P. Tadeschi, A. Capece, A. Maietti, D. Mazzotta, G. Salzano, A. Paparella and P. Romano. Saccharomyces cerevisiae wine strains differing in copper resistance exhibit different capability to reduce copper content in wine. World Journal of Microbiology and Biotechnology, 18, 499-503 (2002)

[12] Chen, C., Wen, D., \& Wang, J. Cellular surface characteristics of Saccharomyces cerevisiae before and after $\mathrm{Ag}(\mathrm{I})$ biosorption. Bioresource Technology, 156, 380-383 (2014)

[13] Vasudevan, P., Padmavathy, V., \& Dhingra, S. Kinetics of biosorption of cadmium on baker's yeast. Bioresource Technology, 89, 281-287 (2003) 
[14] Suh, J., Kim, D., Yun, J., Song, S., Kim, D., Yun, J., et al. Process of $\mathrm{Pb} 2+$ accumulation in Saccharomyces cerevisiae. Biotechnology Letters, 20, 153-156 (1998)

[15] Brady, D., \& Duncan, J. Bioaccumulation of metal cations by Saccharomyces cerevisiae. Applied Microbiology and Biotechnology, 41, 149-154 (1994)

[16] García-Esparza, M. A., Capri, E., Pirzadeh, P., \& Trevisan, M. Copper content of grape and wine from Italian farms. Food Additives \& Contaminants, 23, 274-280 (2006)

[17] Nel, A., Krause, M. and Khelawanlall, N. A Guide for the Control of Plant Diseases. (National Department of Agriculture, Republic of South Africa), 2 (2003)

[18] Provenzano, M. R., El Bilali, H., Simeone, V., Baser, N., Mondelli, D., \& Cesari, G. Copper contents in grapes and wines from a Mediterranean organic vineyard. Food Chemistry, 122(4), 13381343 (2010)

[19] Amerine, Maynard Andrew. The technology of wine making, 4, 794 (1980)

[20] Wurdig, G. "Methodes d'elimination des metaux dans le mout et le vin." Office Int Vigne Vin Bull (1971)

[21] Chervaneva, V. V., S. T. Tiurin, and I. N. Okolelov. "On iron and copper content in wines." Vinodelie Vinogradarstvo Sssr (1971)

[22] Miele, A. Teores de manganês e de cobre no mosto das uvas 'Isabel' e 'Concord'. Pesquisa Agropecuária Brasileira, 22 (09-10), 897-901 (1987)

[23] Manfroi, L., Miele, A., Rizzon, L. A., \& Barradas, C. I. Composição química do mosto da uva Cabernet Franc conduzida no sistema lira aberta. Ciênc. Agrotec., Lavras,30(4), 787-792 (2006)

[24] Debastiani, G., Leite, A. C., Junior, C. A. W., \& Boelhouwer, D. I. Cultura da Uva, Produção e Comercialização de Vinhos no Brasil: Origem, Realidades e Desafios. Revista CesumarCiências Humanas e Sociais Aplicadas, 20(2) (2016)

[25] Amorim, L., Kuniyuki, H., Kimati, H., Amorim, L., Rezende, J. A. M., Bergamin Filho, A., \& Camargo, L. E. A. Doenças da videira (Vitis spp.). Kimati, H.; Amorim, L.; Rezende, JAM; Bergamin Filho, A, 639-651 (2005)

[26] Chaves López, C., Boselli, E., Piva, A., Ndaghijimana, M., Paparella, A., Suzzi, G., \& Mastrocola, D. Influence of quinoxyfen residues on
Saccharomyces cerevisiae fermentation of grape musts. Food Technology and Biotechnology, 42(2), 89-97 (2004)

[27] Zwietering, M. H., Jongenburger, I., Rombouts, F. M., \& van't Riet, K. Modelling of the bacterial growth curve. Applied and Environmental Microbiology, 56, 1875-1881 (1990)

[28] Rinaldi, S.; Tiano, A.; Serban, S.; Pittson, R.; Lajic, Z.; Politi, H.; El Murr, N.; Armani, A.; Cavazza, A. Monitoring wine quality and fermentation kinetics with innovative technologies. In: XXIX Congreso mundial de la viña y el vino: 4a asamblea general de la O.I.V.. Madrid: Ministerio de agricultura, pesca y alimentación: p. 10 (2006)

[29] O’Neill, B., van Heeswijck, T., \& Muhlack, R. (2011). Models for predicting wine fermentation kinetics. Chemeca 2011: Engineering a Better World: Sydney Hilton Hotel, NSW, Australia, 18-21 September 2011 (1956)

[30] Huang, L. Integrated Pathogen Modeling Program. USDA Agricultural Research Service, Eastern Regional Research Center, Wyndmoor, PA (2013)

[31] Silva, F. A. S. ASSISTAT-Assistência Estatística, versão 7.6. Universidade Federal de Campina Grande-PB (2013)

[32] Ferreira, J., Toit, M., \& Toit, W. D. The effects of copper and high sugar concentrations on growth, fermentation efficiency and volatile acidity production of different commercial wine yeast strains. Australian Journal of Grape and Wine Research, 12(1), 50-56 (2006)

[33] Cavazza, A., Guzzon, R., Malacarne, M., \& Larcher, $\mathrm{R}$. The influence of the copper content in grape must on alcoholic fermentation kinetics and wine quality. A survey on the performance of 50 commercial Active Dry Yeasts. VITIS-Journal of Grapevine Research, 52(3), 149 (2015)

[34] Sun, X., Liu, L., Zhao, Y., Ma, T., Zhao, F., Huang, W., \& Zhan, J. Effect of copper stress on growth characteristics and fermentation properties of Saccharomyces cerevisiae and the pathway of copper adsorption during wine fermentation. Food chemistry, 192, 43-52 (2016)

[35] Brandolini, V., Tedeschi, P., Capece, A., Maietti, A., Mazzotta, D., Salzano, G., ... \& Romano, P. Saccharomyces cerevisiae wine strains differing in copper resistance exhibit different capability to reduce copper content in wine. World Journal of Microbiology and Biotechnology, 18(6), 499-503 (2002) 